\title{
GPR55: signaling pathways and functions
}

Nariman Balenga ${ }^{1}$, Ralf Schröder ${ }^{2}$, Julia Kargl ${ }^{1}$, Wolfgang Platzer ${ }^{1}$,

Stefanie Blättermann ${ }^{2}$, Ákos Heinemann ${ }^{1}$, Evi Kostenis ${ }^{2}$ and Maria Waldhoer*1

\author{
Address: ${ }^{1}$ Institute of Experimental and Clinical Pharmacology, Medical University of Graz, 8010 Graz, Austria and ${ }^{2}$ Section Molecular, Cellular \\ and Pharmacobiology, Institute for Pharmaceutical Biology, University of Bonn, 53115 Bonn, Germany \\ Email: Maria Waldhoer* - maria.waldhoer@medunigraz.at \\ * Corresponding author
}

from I5th Scientific Symposium of the Austrian Pharmacological Society (APHAR) Joint meeting with the Hungarian Society of Experimental and Clinical Pharmacology (MFT) and the Slovenian Pharmacological Society (SDF)

Graz, Austria. 19-21 November 2009

Published: 12 November 2009

BMC Pharmacology 2009, 9(Suppl 2):A3 doi: I0. I 186/I47| I-22 I0-9-S2-A3

This abstract is available from: http://www.biomedcentral.com//47I-22/0/9/S2/A3

(C) 2009 Balenga et al; licensee BioMed Central Ltd.

\section{Background}

We have recently shown that the $G$ protein-coupled receptor 55 (GPR55) mediates intracellular effects of cannabinoids and other, non-cannabinoid ligands in addition to the classical cannabinoid $1\left(\mathrm{CB}_{1}\right)$ and $2\left(\mathrm{CB}_{2}\right)$ receptors. Here we show different signaling pathways triggered by GPR55 in response to a panel of its agonists. In addition the cytoskeleton rearrangement mediated by GPR55 is investigated.

\section{Methods}

HEK-293 cells stably expressing the GPR55 receptor were characterized in terms of signaling properties. To this end, FLEX calcium release, reporter gene, dynamic mass redistribution (DMR) and phalloidin actin staining assays have been performed.

\section{Results}

Here we show that GPR55 is activated by lysophosphatidylinositol (LPI), AM251, SR141716A (rimonabant) and AM281. GPR55 activation induces intracellular calcium release, NF-кB, NFAT and CREB activation. Stimulation of GPR55 induces F-actin formation under the control of Ga13, RhoA and ROCK. We also show the suitability of Corning ${ }^{\circledR}$ Epic ${ }^{\circledast}$ DMR assay for GPR55 ligand screening.

\section{Conclusion}

GPR55 as the novel cannabinoid receptor triggers distinct signaling pathways in response to LPI and some classical $\mathrm{CB}_{1}$ receptor antagonists. Stress fiber formation mediated by GPR55 might show the function of this receptor in vivo. 